\title{
A VOZ DE JAMES JOYCE
}

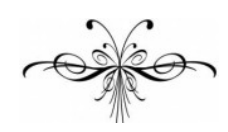

\section{SÉRGIO MEDEIROS}

$\mathrm{U}$

m pequeno seixo na mão de Nora Barnacle. Com essa imagem o escritor irlandês James Joyce (1882-1941) buscou descrever a si mesmo numa das cartas a sua mulher, reunidas neste volume. Ao lado dessa irlandesa monumental, Joyce, mero seixo, havia escolhido viver no exílio para sempre.

Nora, segundo Joyce, era a pequena Irlanda de olhos estranhos. Mais do que uma mulher, mais do que uma musa convencional, Nora era um país, ou melhor, a sua ilha natal, que, ao consentir em exilar-se com ele, iria acompanhálo, desde então, em suas muitas perambulações pelo continente europeu. (As cartas de Joyce, neste volume, descrevem particularmente o vaivém do artista entre a Itália e a Irlanda, e é a sua separação de Nora, que permaneceu no continente, que as justifica.) Na verdade, segundo a imagem anterior, era Nora quem carregava Joyce (e os dois filhos do casal, Giorgio e Lucia) e não o contrário.

Nora foi a ilha natal que deu a Joyce uma mão. Essa imagem não é inócua ou artificial. É verdadeira. E é irônica. Nora não é a Ireland que Joyce afirmava odiar. E que o teria realmente traído...

Os críticos costumam associar Nora à mulher analfabeta do poeta inglês William Blake, sobre quem Joyce escreveu um ensaio, em que propõe a distinção entre mulher simples e mulher cultivada. Ambos, Blake e Joyce, teriam optado pela primeira, pois a outra lhes inspirava desconfiança.

Numa passagem conhecida do seu ensaio de 1912 sobre William Blake, lemos esta declaração de Joyce:

Como numerosos outros gênios, Blake não se sentia atraído por mulheres cultas ou refinadas. Às afetações de refinamento de salão e a uma cultura ampla e fácil, preferia (permitam-me o empréstimo de um clichê do jargão teatral) a mulher simples, de mentalidade nebulosa e sensual, ou, em seu egoísmo ilimitado, desejava que a alma de sua amada fosse uma criação lenta e dolorosa sua, liberando e purificando diariamente, diante de seus próprios olhos, o demônio (tal como dizia) oculto na névoa. ${ }^{1}$

\footnotetext{
${ }^{1}$ JOYCE, James. De santos e sábios: escritos estéticos e políticos. Sérgio Medeiros e Dirce Waltrick do Amarante (orgs.). São Paulo: Iluminuras, 2012, p. 232.
} 


\section{SÉRGIO MEDEIROS}

A palavra "gênio", citada acima, era um epíteto que o próprio Joyce se dava. Ele era um seixo na mão da musa e também um gênio, como Dante, que buscou a sua Beatriz no Paraíso, o lugar mais sublime do Universo. Nora, por sua vez, era, nesse contexto, inicialmente apenas a mulher simples, a mulher que, diga-se de passagem, ainda não aparecia como tal nos seus primeiros escritos, nos versos originais do livro Música de câmara, no qual a figura feminina idealizada por Joyce (este conheceu Nora posteriormente) não era tão "nebulosa e sensual" como veio a se tornar. Aos poucos, porém, a mulher simples assumiu o seu papel e foi adquirindo, na sua vida e na sua obra, outra dimensão, até se tornar, finalmente, como disse, monumental. Daí se compreende o culto de Joyce a Nora Barnacle, transformada na pequena Irlanda, musa sublime e abjeta, linda e suja.

Mas como ela pôde se tornar isso, sendo como era uma simples mocinha do interior?

As cartas amorosas e eróticas que Joyce escreveu a Nora podem ajudar o leitor a encontrar uma resposta. Ao mesmo tempo que Joyce instiga sua mulher a escrever "obscenidades", ele também sugere que foi ela quem o introduziu na prática da escrita suja, vazada em baixo calão, que tanta repercussão teria na sua obra literária, não poucas vezes acusada de obscena. Sem dúvida, a origem das epifanias obscenas de Joyce está nas cartas altamente eróticas. Pudicamente, Joyce assume que era incapaz de dizer em voz alta um único palavrão, e também afirma que raramente sentia vontade de rir de ditos e anedotas licenciosos. Isso em público. Em casa, ao lado de Nora, ou longe dela, por meio de cartas, fazia uso de todo um vocabulário "pesado", o qual esta tradução das cartas procurou preservar em português.

Já se afirmou que Joyce nunca pretendeu escrever cartas literárias a Nora Barnacle. Pediu que ele guardasse essas cartas, mas não as considerava talvez obras de arte. Escritas no calor da hora, as cartas não aspiram de fato a atingir a perfeição formal, embora, em muitos momentos, reproduzam magistralmente, graças ao ritmo acelerado ou irregular, aquilo que Joyce visava a expressar: a inquietação, o frenesi, o gozo... Bastante econômico nas vírgulas, Joyce também omite sinais (como o de interrogação) e tampouco sublinha ou destaca palavras estrangeiras. Nesse sentido, as cartas eróticas são sujas, duplamente sujas. A tradução para o português brasileiro tratou de preservar essa sujeira da voz de Joyce, inclusive ao misturar pronomes pessoais ou embaralhar, em nome da espontaneidade, as normas cultas e a prática coloquial.

Nora é o centro destas cartas, porém não tivemos acesso às suas respostas. As publicações que consultamos durante o trabalho de tradução não nos deram integralmente a voz de Nora.

As cartas de Joyce foram retiradas do volume Selected Letters of James Joyce (Nova York: The Viking Press, 1975), editadas por Richard Elmann.

Sérgio Medeiros

panambi@matrix.com.br

Prof. doutor, Universidade Federal de Santa Catarina 